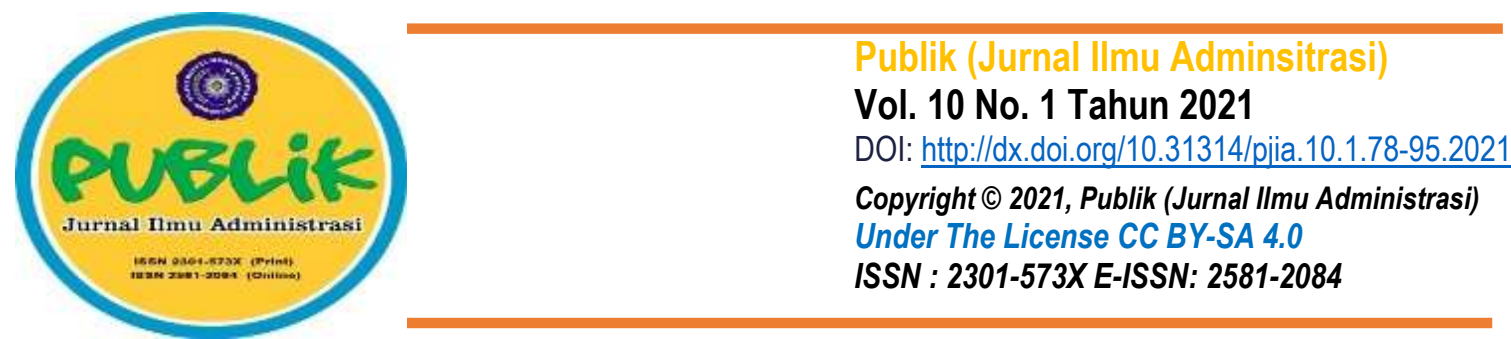

\title{
Analysis of Policy Implementation on The Duties and Functions of the Cabinet Secretariat (Case Study: Function of Policy Recommendation)
}

\author{
Johan Kurniawan ${ }^{1}$, Roy Valiant Salomo ${ }^{2}$ \\ ${ }_{1 * 2}$ Program Pascasarjana Fakultas IImu Administrasi, Universitas Indonesia \\ Email: jobs.johankurniawan@gmail.com, roy.v09@ui.ac.id
}

Abstract. The implementation of the duties and functions of government institution in the President's closest circle, is an interesting thing to research. Its strategic position does not necessarily make its role carried out optimally. This can be seen from the function of providing policy recommendations carried out by the Cabinet Secretariat. Problems such as the disobedience of stakeholders to the flow of policy submissions, as well as problems on administrative matters such as supporting rules, communication strategies, information technology support, the effectiveness of policy monitoring, and the implementation of sanctions, have made the implementation of such functions not run optimally. Therefore, this study aims to analyze the implementation of the function of providing policy recommendations by the Cabinet Secretariat. The analytical framework used in this study is Policy Implementation Theory, particularly the Administrative Implementation Model by Matland (1995). This research uses the qualitative method that is descriptive analysis, with focus of the research is the Cabinet Secretariat in the period 2015 until now. The result of this study is the implementation of the function of providing policy recommendations in dealing with various challenges and problems. However, improvement efforts have been made so that the performance of the function of providing policy recommendations, which is the main performance of the Cabinet Secretariat, can be more optimal.

Keywords: Policy Implementation; Policy Recommendations; Cabinet Secretariat; Duties and Functions.

Received: 07-05-2021 Revised:10-06-2021 Accepted:15-06-2021

\section{INTRODUCTION}

The Cabinet Secretariat of the Republic of Indonesia is an institution that is in the "closest circle" of the President. It has a strategic position where the President's directives and decisions are conveyed through this institution, so that it has the opportunity to be actively involved in the state policy-making process. The duties and functions given through the rule of law further strengthen the authority of the Cabinet Secretariat in policy management.

In the concept of public policy, the duties and functions of government institutions are one type of public policy, in this case, the type of constituent policy (Anderson, 2011). In this type, the government seeks to regulate itself through the establishment of institutions, organizational 
structures, duties, and functions, as well as other supporting matters, wherein this institution later government policies, will be born. With its duties and functions, the Cabinet Secretariat has an important role in the policy-making process in Indonesia.

Article 2 of Presidential Regulation Number 25 of 2015 concerning Cabinet Secretariat, as amended in Presidential Regulation Number 55 of 2020, states that the task of Cabinet Secretariat is to provide cabinet management support to the President and Vice President in running the government. Furthermore, Article 3 explains that in order to carry out this task, the Cabinet Secretariat is given several functions, one of which is to provide recommendations on policies made by the President and Ministries/Institutions.

This recommendation is the result of an analysis that aims to ensure that the draft of a policy, as well as that which is being implemented by the Ministries/Institutions, is in accordance with the vision, mission and direction of the President, and does not conflict with the prevailing laws and regulations. It is also intended to make policies that are more targeted, acceptable, and beneficial to the country. In the Cabinet Secretariat Performance Report, recommendations are always in the "Target 1" category, which indicates that the function is the main task of this institution.

However, as the policy implementation theories suggest, that the implementation of a policy has greater challenges than its formulation process, so that policies written on paper are not necessarily followed by ideal implementation. Udoji (1981, dalam Agustino, 2017) thinks that policy will only be a plan or concept on paper if it is not realized through proper implementation. Furthermore, Khan dan Khandaker (2016) argue that successful policies are not only seen from good design, but also in managing their implementation.

Challenges in implementation also occur in the function of providing policy recommendations implemented by the Cabinet Secretariat. For example, based on the 2019 Performance Report document, the Cabinet Secretariat issued 83 recommendations for the initiative permit of draft legislation throughout the year. However, based on data from the National Legal Document and Information Network/JDIHN, in the same year, the government issued 86 Government Regulations, 97 Presidential Regulations, 22 Presidential Decrees, and 6 Presidential Instructions, with a total of 211 laws and regulations. Based on both data, there is a difference of 128 laws and regulations compared to the number of recommendations produced. This raises the question of whether all draft legislation from the Ministries/Agencies are always requested for recommendations of initiative permits to the Cabinet Secretariat in accordance with the mandate of Presidential Regulation number 25 of 2015. 
Other implementation problems can be seen in the publication of several Presidential Regulation that were strongly criticized by the public. One of them is Presidential Regulation No. 39 of 2015, which was issued on March 23, 2015 regarding the increase of advanced facilities for the purchase of private cars for state officials. As published in media, the Chairman of the House of Representatives through a letter numbered: AG/00026/DPR RI///2015 on January 5, 2015, proposed an increase in the amount of vehicle purchase advance allowance for state officials. In the letter, the Cabinet Secretary submitted a recommendation to the Minister of Finance to consider the proposal (cnnindonesia.com, 2015). Through the letter with number S-114/MK.02/2015, the Minister of Finance responded to the Letter of the Cabinet Secretary who had essentially considered the request of the Speaker of the House and will follow up the request through the presidential regulation on the increase of the Official Down Payment Facility.

Consequently, this policy received severe criticism from the public, as it was considered not concerned with the poor economic condition of the community. Finally, on April 8, 2015, through Presidential Regulation No. 42 of 2015 concerning the revocation of Presidential Regulation No. 39 of 2015 , the increase in the advance allowance for the purchase of official cars was canceled.

These problems are examples of the implementation of duties and functions carried out by the Cabinet Secretariat. Despite being in the President's closest circle, the implementation of the role of this institution still faces various challenges. Therefore, taking into account the strategic position of the Cabinet Secretariat and its duties and functions researchers are interested in analyzing the implementation of the duties and functions of the Cabinet Secretariat, especially the function of providing policy recommendations. The question of this research is how is the implementation of the function of providing recommendations implemented by the Cabinet Secretariat? and,what factors can affect the implementation of this function?

To analyze the problems in this study, researchers conducted a review of previous literature, both in national and international journals. However, based on this review, there are still very few studies examining the role of the Cabinet Secretariat or similar institutions, especially in the last 10 years.

Several studies examining the Cabinet Secretariat were conducted by Shinoda (2005) with an article titled "Japan's Cabinet Secretariat and Its Emergence as Core Executive". This research reveals about the role problems experienced by the Cabinet Secretariat in Japan prior to the Administrative Reform. At that time, Cabinet Secretariat in Japan were rarely involved in policy management. The role of these institutions was passive, only limited to certain policies, and only act when there was a request from other Ministries. This condition is partly due to political factors, 
where the Prime Minister often gives policy authority to the supporting party than to the Cabinet Secretary.

However, after the Administrative Reform, institutional arrangements were carried out, One of which was the dissolution of several Ministries and the strengthening of Ministries/Institutions that were considered important, both in the context of tasks and functions as well as organizational structures and capacities (Seno, 2020). For example, the role of the Cabinet Secretariat is strengthened to be a policy coordinator, even politically above other Ministries/Institutions.

Another study revealed the dynamics of the relationship between the Cabinet Secretariat and the President which was studied by Bertelli \& Grose (2007) through their article entitled "Agreeble Administrators? Analyzing the Public Positions of Cabinet Secretaries and Presidents". The results of this study reveal that the relationship between the Cabinet Secretary and the President of the United States is not always in line. In some cases, the Cabinet Secretary have different attitudes to the President, even when dealing with Congress. One of the differences in attitude is about the discussion of the state budget which results in a difference of opinion between the two.

The campaign promise factor and the aspirations of the district community during the election is one of the reasons the Cabinet Secretary prioritizes the aspirations of the people of his district compared to the President's decision. When the Cabinet Secretary is more in line with congressional policy, the President's takes discretion whose impact is also felt by the Cabinet Department (Bertelli, 2016). In the ideal concept, the Cabinet Secretary as the President's "right hand" should always follow the direction and even try to ensure that the policies of the ministries following the direction of the President. However, based on this case, it shows that the political relationship between the Cabinet Secretary and the President is dynamic and not always in a linear line.

Furthermore, research on similar institutions in Australia was conducted by Hamburger dan Weller (2012) under the title of "Policy Advice and a Central Agency: The Department of the Prime Minister and Cabinet (DPMC)". The results of this study revealed that the role of policy advice implemented by DPMC plays a role in the birth of Australian government policies. In addition, the policy network, as well as the role of civil servants and organizational leaders, will influence the process Of creating a government policy. Therefore, the ability of civil servants in discussing problems in the preparation of recommendations and responsiveness in seeing the developing situation is very necessary. 
The only research on the Cabinet Secretariat in Indonesia related to public policymaking was researched by (Susanto, 2019) through his article entitled Urgency of The Use of Regeling Instruments in the Establishment of Government Policies in the Cabinet Secretariat Environment. This study analyzes the urgency of the use of legal analysis instruments in the formation of government policies conducted by the Cabinet Secretariat. The results of the study revealed that the use of such instruments is indispensable in the implementation of the function of granting approval of initiative permits draft legislation.

Based on several previous studies that have been briefly described above, this research is different because the analysis of the role of the Cabinet Secretariat is reviewed in the framework of policy implementation and focuses on the implementation of the duties and functions of the Cabinet Secretariat. Unlike the case with research Shinoda (2005) ; Hamburger \& Weller (2012) which analyzes from the perspective of institutional politics, research by Bertelli \& Grose (2007) which analyzes from the perspective of the political relations of the Cabinet Secretary and the President, and Susanto (2019) which analyzes from a legal perspective. Thus, in previous studies no one has analyzed the role of the Cabinet Secretariat institution in the framework of implementing policies on the duties and functions of government institutions. This difference is the novelty of this research which is expected to contribute to the development of the study of administration and public policy.

Related to the implementation of policies in hierarchical government institutions, Professor Richard Matland (1995) developed an implementation model which he called the Administrative Implementation Model. This model uses a top-down approach with the assumption that government institutions have a low level of conflict and policy ambiguity. The main principle in this model is that implementation is influenced by the available resources, among others, first, a set of rules and standard operating procedures are established to ensure the policies run well. Second, implementation problems sometimes arise due to poor communication and coordination. For this reason, the communication factor will determine the performance of policy implementation. Third, the information technology has an important role in supporting policy implementation. Fourth, the effectiveness of monitoring is one of the determining factors for the success of policy implementation. And fifth, the level of compliance and the imposition of sanctions also affect the success of implementation. In this model, implementation tends to be influenced by the available resources, thus the problems that arise tend to be technical in nature. The Administrative Implementation Model is used as an analytical framework in examining the problems of this research 
This study aims to provide a clear description and analysis of the implementation of the function of providing recommendations carried out by the Cabinet Secretariat. In addition, it also provides an analysis of the factors that influence the implementation of the recommendation function. Through this research, it is hoped that it can contribute to enriching the study of public administration and policy, especially those with the theme of public policy implementation.

\section{METHODS}

This study uses a post-positivist approach with qualitative methods that are descriptive analysis. Based on the explanations of Creswell (2012), Neuman (2014), and Richie dan Lewis (2003), qualitative research with a post-positivist approach opens up opportunities for researchers to use their knowledge base, in this case, the theory of policy implementation, and remains based on facts and conditions happens in the field. This is intended so that the analysis of the implementation of the function of providing policy recommendations carried out by the Cabinet Secretariat is clearly and comprehensively illustrated based on the data obtained, but also still based on the analytical framework of Policy Implementation Theory. The focus of this research is the implementation of the function of providing policy recommendations carried out by the Cabinet Secretariat and the factors that influence it, in terms of the Administrative Implementation Model proposed by Matland (1995).

The data collection technique used in this study is through analysis of related literatures, such as Performance Report, Strategic Plan of Cabinet Secretariat, regulations governing the implementation of such functions, news from credible sources such as daily kompas.com, cnnindonesia.com, and other news sources. In addition, to enrich the data, researchers also conducted in-depth interviews with informants from the Cabinet Secretariat, namely the Head of Subfield at the Cabinet Secretariat, as well as 2 informants from the Coordinating Ministry for Economic Affairs who are the main stakeholders of the Cabinet Secretariat, namely assistant deputies and subfield heads in the Coordinating Ministry for Economic Affairs. Interviews are conducted based on the interview guidelines that have been compiled.

The data analysis technique used is as proposed by Miles dan Huberman (2014), namely first, reducing the overall data obtained by coding and categorization. Second, interpreting the data to get the meaning of the data obtained in relation to the theory used. And finally, draw conclusions, so that the resulting research is expected to be valid based on written evidence, have strong arguments, and be scientific in the framework of Policy Implementation Theory. 


\section{RESULTS AND DISCUSSION}

Policy implementation is a crucial stage in the policy cycle because at this stage the policy is translated into action (O'Toole, 2000 ; Fischer \& Miller, 2017) or in a legal context, at this stage a statutory regulation becomes an applied law (Stewart, 2000). In generally, policy implementation is basically how a policy achieve its objectives (Rangkuti \& Maksum, 2019).

Likewise, the duties and functions of government institutions are established through legislation and regulations, usually at the level of a Presidential Regulation. When the regulation was enacted, the obligation for the implementer to implement the mandate given by the Presidential Regulation.

In principle, policy implementation must prioritize the effectiveness of the policy itself (Putera et al., 2020). However, at this stage of implementation, obstacles often arise due to the surrounding factors. In proving that a policy is implemented effectively, some of the ways are by checking a gap between policy objectives expected with the results obtained (McConnell, 2015), as well as to the achievement of the performance, the level of barriers, as well as the problems faced in the implementation (Hill \& Hupe, 2013). From these analyzes, it will be seen how effective a policy is when it is implemented.

The discussion below describes the analysis of the implementation of the function of providing policy recommendations carried out by the Cabinet Secretariat as well as the factors that influence the implementation.

\section{Implementation of Policy Recommendation Function}

Provision of policy recommendations is the main output of the Cabinet Secretariat's performance. This is a manifestation of the function given by Presidential Regulation No. 25 of 2015 on the Cabinet Secretariat which has been amended in Presidential Regulation No. 55 of 2020. The recommendations produced can be in the form of consideration of approval, consideration of rejection, and can also be in the form of a reminder if there is a Presidential directive that needs to be followed up.

For example, in the 2020 Cabinet Secretariat Performance Report/Laporan Kinerja Sekretariat Kabinet Tahun 2020, the Minister of Trade submitted a request for approval to the President through the Cabinet Secretariat regarding the draft regulation concerning Provisions for Business Licensing, Advertising, Guidance, and Supervision of Business Actors in Trading through the Electronic System. Based on the results of the study and analysis carried out by the Cabinet Secretariat, a memorandum was submitted to the President with the number: 
M.0488/Seskab/05/2020 dated May 19, 2020, in which the Cabinet Secretary provided recommendations for consideration regarding the need for the Ministerial Regulation. In the end, after being approved by the President, the Minister of Trade Regulation Number 50 of 2020 was issued regarding this matter.

Another example is related to the moratorium on the construction of new buildings for government agencies, which the Minister of State Apparatus Utilization and Bureaucratic Reform submitted an application for the construction of a new building for the Ministry of State Apparatus Utilization and Bureaucratic Reform. However, based on the results of the study conducted, the Cabinet Secretariat then submitted a recommendation for consideration that the plan was not appropriate to be implemented at that time due to the President's directive regarding the moratorium on the construction of new government buildings. Finally, the consideration was conveyed through letter number: B.0199/Seskab/Polhukam/05/2019 dated 27 May 2019 to the Minister of State Apparatus Utilization and Bureaucratic Reform (Cabinet Secretariat Performance Report, 2019/Laporan Kinerja Sekretariat Kabinet, 2019).

Based on the 2019 Cabinet Secretariat Performance Report, in the last 5 years, the percentage of utilization of the policy recommendations produced by the Cabinet Secretariat is above $90 \%$. From the table 1 , it can be seen the fluctuations of the achievements on the utilization of the recommendations made over the years. This indicates that the implementation of these functions does not always achieve the expected target so that improvements need to be done. One of the important notes from the table is that in 2018 there was a drastic decrease in the utilization of recommendations in granting recommendations for statutory initiative permits, which only reached $92.25 \%$. Of the 129 recommendations produced, only 119 recommendations were utilized and 10 recommendations did not reach the target because these recommendations were returned and not followed up on to the Stakeholders. This condition is an illustration of the dynamics in the implementation of the recommendation function, where some of the recommendations produced are utilized and some are not.

The recommendations made by the Cabinet Secretariat are not only delivered in written form such as through memorandums and letters but can also be delivered directly in interministerial meeting forums. The Head of Sub-Section at the Coordinating Ministry for Economic Affairs explained that in inter-ministerial meetings, the Cabinet Secretariat was often asked for opinions and recommendations. 
Table 1

Recommended Utilization Percentage Table

\begin{tabular}{|c|c|c|c|c|c|c|}
\hline $\begin{array}{l}\text { Key Performance } \\
\text { Indicators }\end{array}$ & $\begin{array}{c}\text { Capaian } \\
2015\end{array}$ & $\begin{array}{c}\text { Capaian } \\
2016\end{array}$ & $\begin{array}{c}\text { Capaian } \\
2017\end{array}$ & $\begin{array}{l}\text { Capaian } \\
2018\end{array}$ & $\begin{array}{c}\text { Capaian } \\
2019\end{array}$ & $\begin{array}{c}\text { Capaian } \\
2020\end{array}$ \\
\hline $\begin{array}{l}\text { Percentage of } \\
\text { policy } \\
\text { recommendations } \\
\text { utilized }\end{array}$ & $98,37 \%$ & $99,12 \%$ & $99,90 \%$ & $100 \%$ & $100 \%$ & $100 \%$ \\
\hline $\begin{array}{l}\text { Percentage of } \\
\text { recommendation } \\
\text { for initiative } \\
\text { permits approval } \\
\text { of draft legislation }\end{array}$ & $100 \%$ & $99,63 \%$ & $100 \%$ & $92,25 \%$ & $100 \%$ & $100 \%$ \\
\hline
\end{tabular}

Moreover, if the discussion is deadlocked, the presence of the Cabinet Secretariat as a representative from the Palace is urgently needed to find a solution that is following the President's direction. Regarding the recommendation for initiative permits, in the introductory section, it was mentioned about the difference in the number of recommendations produced by the Cabinet Secretariat with the laws and regulations issued in 2019, namely the difference between 128 laws and regulations. When linked with Recommended Utilization Percentage Table above, the percentage of achievement category granting permission on the initiative of the legislation in 2019 reached the perfect number, namely $100 \%$.

From this data, it can be concluded 2 things, first, all applications for permits for the initiative of laws and regulations submitted to the Cabinet Secretariat, are followed up thoroughly by this institution. Second, not all draft laws and regulations drawn up by Ministries/Institutions require a recommendation for approval of initiative permits to the Cabinet Secretariat as it should be based on the mandate of Presidential Regulation Number 25 of 2015. This condition also provides an illustration that the flow of submission of draft laws and regulations has not fully carried out by the Ministries/Agencies.

Based on the author's interview with the Deputy Assistant at the Coordinating Ministry for Economic Affairs, it was stated that the distribution of the flow of initiative permits for draft legislation, in which the submission of initiative permits was submitted to the Ministry of State Secretariat while the recommendation for approval was asked to the Cabinet Secretariat, causing confusion for Ministries/Institutions. It is considered potentially lead to the draft legislation not to be 
communicated to the Secretariat of the Cabinet. According to him, this process should be handled by only one institution, starting from "upstream to downstream", so that it will be more effective and not cause confusion.

However, even though there are problems in the implementation of initiative permit flow of the draft legislation, but in the substance formulation stage, the Cabinet Secretariat is always involved. This can be concluded from the statement of the Head of Subfield at the Coordinating Ministry for Economic Affairs which stated that at every policy discussion meeting, the Cabinet Secretariat was always actively involved and asked for its opinion.

\section{Factors Affecting the Implementation of the Recommendation Function}

Based on the Policy Implementation Model developed by Matland, 1995 it is explained that in government institutions that adopt a top-down approach and have a low level of conflict and ambiguity, implementation is influenced by the available resources and administrative factors, such as supporting regulations, the quality of implementing communications, information technology support, monitoring effectiveness, as well as the level of compliance and the existence of sanctions. These factors are also important elements in the implementation of the function of providing recommendations carried out by the Cabinet Secretariat.

\section{Supporting Regulations}

In addition to the main regulations, namely Presidential Regulation Number 25 of 2015 and Presidential Regulation Number 55 of 2020, other laws and regulations that have an influence in supporting the function of providing recommendations to the Cabinet Secretariat is Presidential Instruction Number 7 of 2017 concerning Adoption, Supervision, and Control of Policy Implementation in Level of State Ministries and Government Institutions. This Presidential Instruction authorizes the Cabinet Secretariat to provide reports with recommendations to the President regarding the follow-up to the President's directives carried out by Ministries/Institutions. The issuance of this Presidential Instruction has had a considerable influence on the Cabinet Secretariat, as well as strengthening the existence of the Cabinet Secretariat in meeting forums between Ministries/Institutions.

The Head of Sub-Section at the Coordinating Ministry for Economic Affairs found that the issuance of Presidential Instruction Number 7 of 2017 makes the Cabinet Secretariat have a strategic position in every policy discussion between Ministries/Institutions. The Cabinet Secretariat acts as a representative of the Palace who carries the President's message, even mediating if there is a deadlock in the discussion. In addition, through the Cabinet Secretariat, reports on the implementation of policies are submitted to the President. Therefore, the issuance of this 
Presidential Instruction further strengthens the involvement of the Cabinet Secretariat in the state policy-making process.

At the technical level, Cabinet Secretary Regulation Number 2 of 2016 concerning Standard Operating Procedures (SOP) has been issued in the Cabinet Secretariat, one of which is to regulate the flow of drafting and providing policy recommendations. In addition, in the context of utilizing information technology to support the function of monitoring the President's directives, a Cabinet Secretary Regulation Number 40 of 2019 was formed regarding the SOP for the Implementation of Follow-Up to the President's Directions through the Information System for Follow-up to the President's Directions (SITAP) within the Cabinet Secretariat. Based on the information from the Head of Sub-Section at the Cabinet Secretariat who is also the executor of this function, with the existence of both SOPs regarding the preparation of policy recommendations as well as regarding the use of SITAP to support this, it further clarifies the responsibilities of implementers from the lower level to the leadership level, making it easier to provide convenience in its implementation.

Currently, the function of granting recommendation for approval of initiative permits for draft laws and regulations that apply to Presidential Regulation No. 25 of 2015 has been removed in line with the enactment of Presidential Regulation No. 55 of 2020. However, in this new Presidential Regulation, the Cabinet Secretariat is given a new function, namely to review and provide recommendations to the President regarding the proposed draft Ministerial Regulation/Head of Institutions that have an impact on the public. Until now, the system for implementing these new functions is still being developed and refined, so that in 2020 the Cabinet Secretariat will still handle recommendations for approval of initiative permits.

\section{Communication}

In implementing the function of providing recommendations carried out by the Cabinet Secretariat, communication is carried out in written form such as through official letters, as well as verbally. This is carried out both at the leadership level to the implementing level, which technical coordination is usually carried out by the implementing level. For example, in the national nasional.tempo.co. (2020) it was stated that through a letter numbered B0144/Seskab/Polhukam/04/2020 dated April 23, 2020, the Cabinet Secretary conveyed the President's direction that the draft Ministerial Regulation/Head of Institutions must first obtain the President's approval before being enacted. This is a directive contained in a limited meeting on 2 July 2015, plenary cabinet sessions on 12 February 2018, and 14 November 2019. In addition, the directive also emphasizes the new function of the Cabinet Secretariat in conducting reviews and 
providing recommendations for approval to the President on the regulation draft of Ministerial/Head of Institution. Official letters are a form of formal communication carried out by the Cabinet Secretariat, especially at the leadership level, which is used to communicate the President's directives and certain considerations.

One of the important forms of communication carried out by the Cabinet Secretariat is in inter-ministerial meeting forums, wherein this forum the Cabinet Secretariat is given space to express its views, especially if there are Presidential directives that need to be confirmed. Based on information from the Head of Sub-Section at the Cabinet Secretariat and Head of Sub-Section at the Coordinating Ministry for Economic Affairs, the communication carried out has gone wellso far. Communication is carried out when a policy is submitted to the Cabinet Secretariat, usually to clarify the required data, seek information on the follow-up actions that have been carried out, and report any obstacles and problems encountered. This well-functioning communication is one of the factors in supporting the implementation of the recommendation-giving function carried out by the Cabinet Secretariat.

\section{Information Technology Support}

Information technology is an important element in supporting the implementation of the duties and functions of the Cabinet Secretariat. However, this support is currently considered not optimal, which reflected in the existing policy and governance aspects. Based on the 2020 Cabinet Secretariat Performance Report, it is stated that the Grand Design of System and Information Technology Development and Development within the Cabinet Secretariat is still based on Cabinet Secretary Regulation Number 56 of 2012 concerning Grand Design of 2011-2014 and refers to the old business process so that it is considered less in accordance with the current organizational conditions and work procedures. Currently, the Master Plan for Information Systems and Information Technology (RISTI) for Electronic-Based Government Secretariat of the Cabinet 2020 - 2024 is being prepared. With this RISTI, it is hoped that the improvement in the quality of information technology support can be fulfilled.

In addition, currently, a SITAP application has been built to oversee the follow-up to the President's directives. The utilization of this application requires adequate information technology support. Currently, the application is already using version 3.0, but in its operation, it still uses an intranet network and access must be via a Virtual Private Network (VPN) which becomes an obstacle in terms of flexibility and ease of use of SITAP. Currently, the application can only be accessed limitedly by the Coordinating Ministry. Even though it is supposed to make it more effective and easier to update the follow-up report on the President's direction, the application can 
be used by all Ministries/Agencies. Due to the importance of the existing policy data in the system, it is also necessary to upgrade an adequate firewall and anti-virus system so that confidential data can be protected and prevent data hacking attempts.

\section{Monitoring Effectiveness}

In the follow-up monitoring system for recommendations produced by the Cabinet Secretariat, there are fundamental problems related to the measurement criteria. Currently, the criteria for monitoring the use of recommendations produced by the Cabinet Secretariat are still very simple, assuming that the recommendations considered to have been utilized if they have been submitted and received a response. The lack of a comprehensive monitoring system has an impact on the emergence of difficulties in assessing the utilization of the outcomes of the recommendations produced. This plays an important note in improving the effectiveness of the recommendation monitoring system that has been produced. Another form of monitoring carried out by the Cabinet Secretariat is by directly observing the implementation of policies in the field. From this monitoring, a report will be produced along with recommendations that will be submitted to the President.

The SITAP application is also an instrument in monitoring policies. However, the Head of Sub-Section at the Coordinating Ministry for Economic Affairs stated that the system had not been utilized optimally. Its utilization is still limited to the fulfillment of the required data fields, not yet making SITAP an important reference in monitoring and formulating policy recommendations.

Currently, the Cabinet Secretariat is also developing an Information System for Monitoring the Approval of Ministerial Regulations/Head of Institutions Regulations (SIPPERMEN), to monitor the implementation of the approval of Ministerial Regulations/Heads of Institutions. Through the system built, it is hoped that the follow-up to the approval of the Ministerial Regulation/Head of Institution can run according to the established flow and direction. Although still not operating effectively, SITAP and SIPPERMEN are innovations and steps forward in supporting the optimization of the duties and functions of the Cabinet Secretariat, particularly the function of providing policy recommendations.

\section{Compliance and Sanctions}

In general, there have been no sanctions given to Ministries/Institutions that do not comply with implementing the stipulated provisions or policy flows. However, if there are steps by the Ministries/Agencies that are deemed inappropriate in implementing existing provisions or directives from the President, the Cabinet Secretary will issue a written warning through an official letter. Unlike the case at the individual implementing level, if there are employees who commit violations 
such as leaking the results of policy recommendations or confidential data, sanctions can be given based on Government Regulation Number 53 of 2010 concerning Civil Servant Discipline, which regulates disciplinary penalties. The sanctions are given in stages, and if the fault is considered fatal, it can be given severe punishment, such as being dismissed from its status as a civil servant. However, so far no employee has been sanctioned for leaking confidential data. As revealed by Matland (1995) that in the Administrative Implementation Model, the compliance level of the implementers at the technical level tends to be good. For this reason, the sanctions that apply to this model tend to be light and administrative in nature.

\section{Analysis of Research Results in the Framework of Policy Implementation and Previous Studies}

The results of the research described above illustrate that the implementation of the function of providing recommendations carried out by the Cabinet Secretariat faces several challenges, such as the policy flow that has not gone well, the need for supporting regulations to strengthen the function of the Cabinet Secretariat, a monitoring system that has not been running effectively, to technical support. information is still not sufficient. The results of this study prove the argument of the Administrative Implementation Model put forward by Matland (1995), that internal technical administrative factors are important factors in influencing the performance of policy implementation.

However, regarding the issue of policy flow that does not go through the Cabinet Secretariat, it indicates that it is necessary to carry out institutional arrangements both in the form of strengthening roles and issuing supporting regulations so that the assigned tasks and functions can be implemented optimally. Japan's experience in carrying out Administrative Reform as stated by Shinoda (2005) and Seno (2020) can be an inspiration for Indonesia in structuring and strengthening the role of the Cabinet Secretariat so that as an institution in the closest circle of the President, it can play a more optimal role in policymaking process.

Based on a review of previous research (see Shinoda, 2005 ; Seno, 2020 ; Hamburger \& Weller, 2012; and Susanto, 2019), it can be concluded several things, first, the existence of the Cabinet Secretariat institution and its role in policy is very necessary. This is because the Cabinet Secretariat is the "right hand" and at the same time assists the President in managing the many policies that the President must handle. Like experiences in the United States, Japan, and Australia, the duties and functions of the Cabinet Secretariat in Indonesia must also run optimally so that the tasks of supporting policy management can run well. 
Second, the results of this study reveal that the Cabinet Secretariat is always in line with the President's policies and continues to strive to be a representative who carries the President's mandate in every policy discussion process. This condition is inversely proportional to the results of research by Bertelli \& Grose (2007) and Bertelli (2016) regarding Cabinet Secretaries in America who in some conditions have different attitudes with the President. The results of this study strengthen the argument of the administrative implementation model, that in the context of government institutions that are top-down and hierarchical and are in a presidential system, the space for conflict or differences in attitudes between policymakers and policy implementing institutions tends to be small. Policy makers' decisions are consistently translated by implementers. However, the phenomenon that occurred in America is a new dynamic in the relationship between the President and the institutions under President.

Third, based on the relationship between research results, previous literature reviews, and policy implementation theory, this study reveals that some non-political factors, such as internal administrative factors also have a major influence on the implementation of the duties and functions of the Cabinet Secretariat, not only those that political nature as other studies previously discussed. This indicates that the administrative aspect also plays an important role in influencing the performance of the institution in playing policy politics. It is hoped that this will add more references to the policy-making process.

\section{CONCLUSIONS}

The implementation of the function of providing policy recommendations carried out by the Cabinet Secretariat faces various challenges that have made this function not run optimally. This is also an important note for improving the performance of the Cabinet Secretariat in the future. In general, the researchers consider that the function of providing recommendations mandated to the Cabinet Secretariat is a very appropriate policy, considering that in the first ring of the President, a party or institution is needed that is given the responsibility to oversee the policies issued by the government as has been discussed regarding the role of the Cabinet Secretariat. or the like in Japan, Australia, Korea, even the United States. For this reason, it is necessary to make improvements both through laws and regulations and organizational arrangements, so that the role of the Cabinet Secretariat through its function of providing policy recommendations becomes more assertive so that the role of the institution which is the "right hand" of the President can be realized in quality and optimally. 


\section{REFERENCES}

Agustino, L. (2017). Dasar-Dasar Kebijakan Publik. Bandung: Alfabeta.

Anderson, J. E. (2011). Public Policymaking: An Introduction. In Public policymaking: an introduction (7th ed.). Boston: Wadsworth Cengage Learning.

Bertelli, A. M. (2016). Bureaucratic Autonomy in the U.S. Separation of Powers: Evidence from Cabinet Departments. Public Organization Review, 16(1), 139-151.

Bertelli, A. M., \& Grose, C. R. (2007). Agreeable Administrators? Analyzing the Public Positions of Cabinet Secretaries and Presidents. Presidential Studies Quarterly, 37(2), 228-247.

Cnnindonesia.com. (2015). Kronologi Perpres Uang Muka Mobil Pejabat Versi Mensesneg. Cnnindonesia.Com. https://www.cnnindonesia.com/ekonomi/20150406121643-7844461/kronologi-perpres-uang-muka-mobil-pejabat-versi-mensesneg

Creswell, J. W. (2012). Research Design: Pendekatan Kuantitatif, Kualitatif,dan Mixed (Edisi Ketiga). Yogyakarta: Pustaka Pelajar.

Fischer, F., \& Miller, G. J. (2017). Handbook of Public Policy Analysis: Theory, Politics, and Methods. In Handbook of Public Policy Analysis: Theory, Politics, and Methods. New York: CRC Press.

Hamburger, P., \& Weller, P. (2012a). Policy Advice and a Central Agency: The Department of the Prime Minister and Cabinet. Australian Journal of Political Science, 47(3), 363-376.

Hill, M., \& Hupe, P. (2002). Implementing Public Policy: Governance in Theory and in Practice. London: SAGE Publication.

Kabinet, S. (2019). Laporan Kinerja Sekretariat kabinet Tahun 2019. https://setkab.go.id/wpcontent/uploads/2020/04/1.-laporan-kinerja-sekretariat-kabinet-tahun-2019.pdf

Kabinet Sekretariat. (2020). Laporan Kinerja Sekretariat Kabinet Tahun 2020. https://setkab.go.id/wp-content/uploads/2021/05/LKj-Sekretariat-Kabinet-Tahun-2020.pdf

Khan, A. R., \& Khandaker, S. (2016). A Critical Insight Into Policy Implementation and Implementation Performance. Public Policy and Administration, 15(4), 538-548.

Matland, R. E. (1995). Synthesizing the Implementation Literature: The Ambiguity-Conflict Model 
of Policy Implementation. Journal of Public Administration Research and Theory, 5(2), 145174.

McConnell, A. (2015). What is Policy Failure? A primer to Help Navigate the Maze. Public Policy and Administration, 30(3-4), 221-242.

Miles \& Huberman, M. (2014). Qualitative Data Analysis: A Methods Sourcebook (3rd ed.). SAGE Publication.

Nasional.tempo.co. (2020, April 26). Beredar Surat Jokowi Minta Menteri Lapor Sebelum Bikin Peraturan. https://nasional.tempo.co/read/1335716/beredar-surat-jokowi-minta-menterilapor-sebelum-bikin-peraturan

Neuman, W. L. (2014). Social Research Methods: Qualitative and Quantitative Approaches (7th ed.). Pearson Education Limited.

O'Toole, L. J. (2000). Research on Policy Implementation: Assessment and Prospects. Journal of Public Administration Research and Theory, 10(2), 263-288.

Putera, R. E., Valentina, T. R., \& Rosa, S. A. S. (2020). Implementasi Kebijakan Penataan Ruang Berbasis Mitigasi Bencana Sebagai Upaya Pengurangan Resiko Bencana di Kota Padang. Publik (Jurnal Ilmu Administrasi), 9(2), 155.

Rangkuti, S. R., \& Maksum, I. R. (2019). Implementasi Kebijakan Sekolah Ramah Anak Dalam Mewujudkan Kota Layak Anak di Kota Depok. Publik (Jurnal IImu Administrasi), 8(1), 38.

Richie, Jane. \& Lewis, J. (2003). Qualitative Research Practice A Guide for Social Science Students and Researchers. London: SAGE Publication.

Seno, R. H. (2020). Strategi Jepang dalam Mereformasi Administrasi: Literatur Review. Sawala, $8(2), 205-223$.

Shinoda, T. (2005). Japan's Cabinet Secretariat and Its Emergence as Core Executive. Asian Survey, 45(5), 800-821.

Stewart, H. \& L. (2000). Public Policy: An Evolutionary Approach. Belmont: Wadsworth Thompson. 
Susanto, H. (2019). Urgensi Penggunaan Instrumen Regeling dalam Pembentukan Kebijakan Pemerintah di Lingkungan Sekretariat Kabinet. Administrative Law and Governance Journal, 2(1), 179-189. 